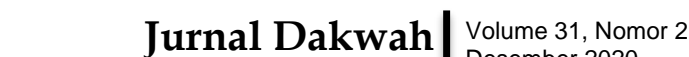

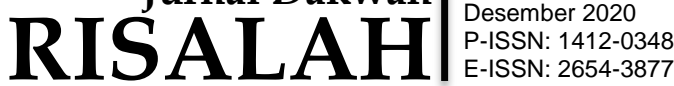 \\ DOI: $10.24014 /$ jdr.v31i2.10874
}

\section{ANALISIS LEGITIMASI ZAKAT PROFESI DARI DIMENSI SYARIAH DAN REGULASI DI INDONESIA}

\author{
Efri Syamsul Bahri ${ }^{1}$, Mohd Mizan Mohammad Aslam ${ }^{2}$, Hendro Wibowo ${ }^{3}$ \\ ${ }^{1,3}$ Sekolah Tinggi Ekonomi Islam SEBI \\ ${ }^{2}$ School of Human Development and Technocommunication Universiti Malaysia Perlis \\ Email: efri.sb@sebi.ac.id
}

\section{Kata kunci}

Legitimasi, zakat profesi, dimensi syariah, dimensi regulasi

Keywords

Legitimation, zakat profession, sharia dimension, regulatory dimension

\begin{abstract}
Abstrak
Total potensi zakat profesi mencapai Rp. 139,07 triliun atau 59,5 persen dari total potensi zakat nasional sebesar Rp. 233,8 triliun. Sedangkan realisasinya baru mencapai Rp. 3,9 triliun atau 2,8\%. Penelitian ini bertujuan untuk menganalisis zakat profesi dari dimensi syariah dan regulasi. Penelitian ini menggunakan metode kualitatif dengan pendekatan deskriptif dan studi pustaka. Bahan kajian diperoleh dengan cara mengumpulkan dan menelaah hasil penelitian sebelumnya yang relevan dengan tema ini. Hasil penelitian menunjukkan bahwa zakat profesi dari dimensi syariah wajib mengikuti teks Alquran dan fatwa ulama dengan persyaratan memenuhi batas nisab. Sedangkan zakat profesi dari dimensi regulasi, bersifat komprehensif. Ini ditunjukkan dengan adanya regulasi pada level makro, meso, dan mikro. Oleh karena itu, zakat profesi memiliki legitimasi yang kuat dan dapat mendorong optimalisasi pencapaian pengumpulam dan pendistribusian zakat.
\end{abstract}

\begin{abstract}
The total potential for zakat profession is IDR. 139.07 trillion, or 59.5 percent of Rp's total national zakat potential. 233.8 trillion. Meanwhile, the realization only reached IDR. 3.9 trillion or $2.8 \%$. This study aims to analyze the zakat profession from the sharia and regulatory dimensions. This study uses a qualitative method with a descriptive approach and literature study. The research data was obtained by collecting and reviewing previous research results that were relevant to the theme. The results showed that zakat profession from the sharia dimension is obliged to follow the text of the Alquran and the fatwas of the ulama to meet the 'nisab' limit. Meanwhile, on the regulatory side, professional zakat is comprehensive. It is indicated by the presence of regulations at the macro, meso, and micro levels. Thus, professional zakat has strong legitimacy and can encourage optimizing the collection and distribution of zakat.
\end{abstract}

\section{Pendahuluan}

Jumlah potensi zakat profesi mencapai Rp139.07 triliun atau 59.5 persen dari total potensi zakat nasional sebesar Rp233.8 triliun (Puskas, 2019). Penghitungan potensi zakat menggunakan pendekatan indikator Pemetaan Potensi Zakat (IPPZ). Keunggulan dari model pengukuran IPPZ adalah dapat menghitung potensi zakat pada suatu wilayah yang menjadi potensi obyek zakat. Penghitungan potensi obyek zakat model IPPZ terdiri dari lima elemen, yaitu: zakat pertanian, zakat peternakan, zakat uang, zakat 
penghasilan dan zakat perusahaan. Model IPPZ ini berbeda dengan model penghitungan sebelumnya. Firdaus et al. menghitung potensi zakat berdasarkan zakat pendapatan yang berasal dari rumah tangga, industri menengah dan besar, serta simpanan masyarakat dalam bentuk tabungan (Firdaus et al., 2012).

Pengukuran potensi zakat model IPPZ dapat dimanfaatkan oleh entitas pengelola zakat untuk mengidentifikasi karakteristik potensi dan strategi pengumpulan zakat. Hasil kajian IPPZ ini menjadi rujukan secara nasional untuk kemajuan pengelolaan zakat di Indonesia. Oleh karena itu, menjadi penting untuk dilakukan sosialisasi dan edukasi model pengukuran IPPZ ini kepada entitas pengelola zakat di Indonesia.

Menurut model IPPZ, salah satu potensi zakat yang dihitung adalah potensi zakat profesi. Hasil penghitungan zakat profesi dengan model IPPZ menunjukkan potensi zakat profesi mencapai Rp139.07 triliun. Ini menggambarkan porsi zakat profesi secara nasional mencapai 59.5\%. Dengan demikian, potensi zakat profesi menjadi yang terbesar. Hasil penghitungan zakat profesi ini selaras dengan jumlah Aparatur Sipil Negara (ASN) yang berjumlah 4,475 juta orang (Tan et al., 2010). Sedangkan, realisasi pengumpulan zakat profesi baru mencapai 2,8\% atau Rp3,95 triliun dari potensinya. Dengan gap realisasi zakat profesi yang begitu besar, maka menjadi penting untuk menganalisis lebih lanjut tentang legitimasi zakat profesi di Indonesia.

Hasil penelitian sebelumnya yang dilakukan oleh Riyadi (2015), terdapat perbedaaan pendapat tentang zakat profesi. Pendapat pertama membolehkan zakat profesi. Ini didukung dengan tiga alasan yaitu: adanya perluasan makna lafaz, qiyas dan mengacu pada tujuan disyariatkannya zakat. Sedangkan pendapat kedua tidak membolehkan. Pendapat yang tidak membolehkan karena tidak pernah dicontohkan oleh Nabi Muhammad SAW. Namun, terlepas dari adanya perbedaan pandangan tersebut, semangat masyarakat muslim untuk menunaikan zakat profesi cukup tinggi (Riyadi, 2015). Namun, hasil penelitian Islamiah \& Romli menunjukkan hal yang berbeda. Menurut Islamiah \& Romli (2019), ASN mempunyai perhatian dan pemahaman tentang zakat profesi. Namun, dalam implementasinya hanya sebagian guru yang secara rutin mengeluarkan zakat profesi (Islamiah \& Romli, 2019). Ini selaras dengan realisasi pengumpulan zakat profesi secara nasional dengan pencapaian baru mencapai $2,8 \%$.

Selanjutnya, berdasarkan data terbaru pemerintah, pengumpulan zakat profesi secara nasional berada pada kategori yang paling besar (Baznas, 2019). Pada tahun 2019, pengumpulan zakat profesi mencapai Rp3,95 triliun atau 38.6\% dari total pengumpulan zakat, infak/ sedekah ditambah dana sosial keagamaan lainnya (ZIS dan DSKL). Pengumpulan ZIS dan DSKL mencapai Rp10,2 triliun. Pengumpulan ini berasal dari semua entitas pengelola zakat yang terdiri dari Baznas, Baznas Provinsi, Baznas Kabupaten/ Kota dan LAZ.

Jenis dana dan porsi pengumpulan zakat, infak/ sedekah dan dana sosial keagamaan lainnya pada Tahun 2019 terdiri dari zakat mal-penghasilan, zakat malbadan, zakat fitrah, infak/ sedekah, CSR dan dana sosial keagamaan lainnya. Secara rinci, jumlah pengumpulan ZIS dan DSKL tahun 2019 disajikan pada Gambar 1 di bawah ini. 


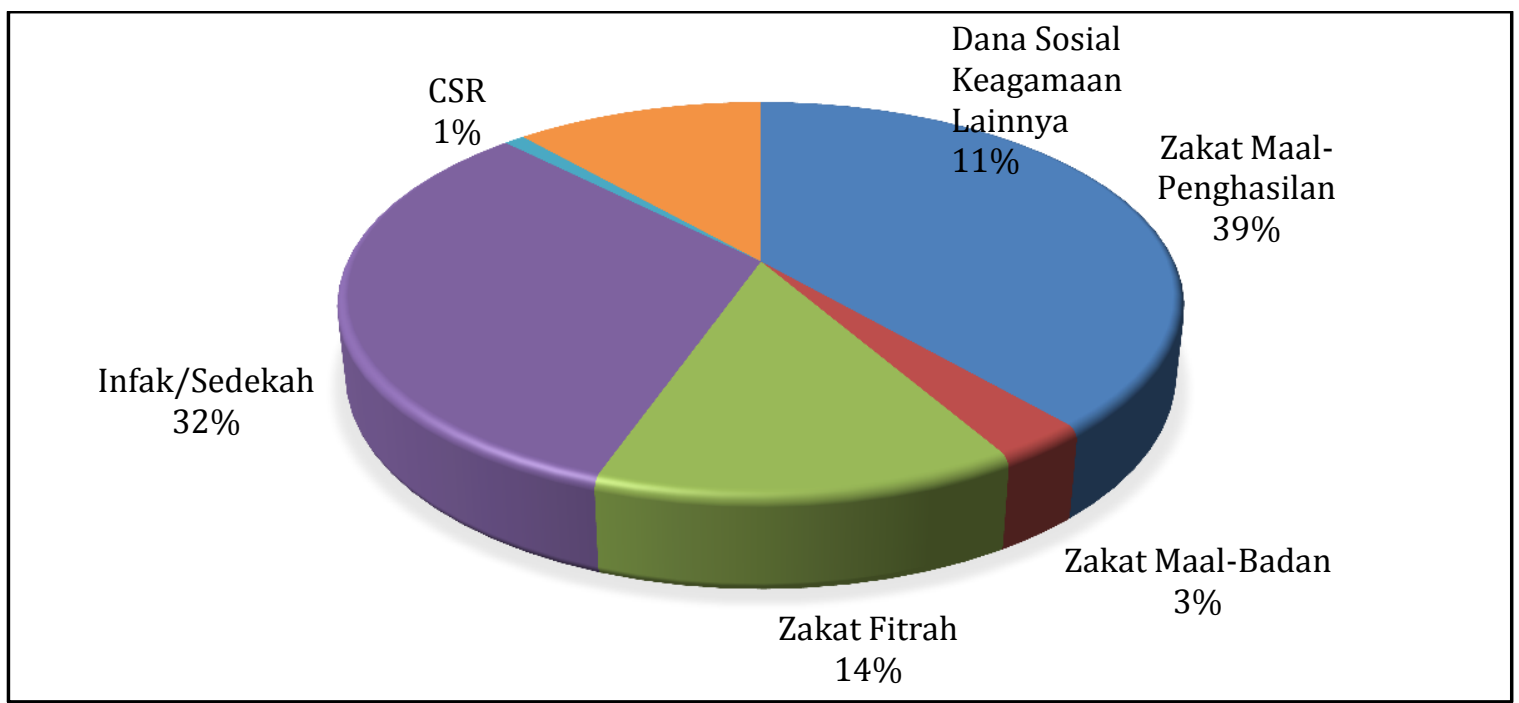

Sumber: (Baznas, 2019)

Gambar 1. Jenis Dana dan Porsi Pengumpulan Zakat, Infak/ Sedekah dan Dana Sosial Keagamaan Lainnya pada Tahun 2019

Belum optimalnya pencapaian realisasi zakat secara nasional disebabkan banyak faktor. Pertama, belum maksimalnya pengumpulan yang dilakukan lembaga zakat (Aibak, 2015). Kedua, peran entitas pengelola zakat yang belum efektif dan efisien (Amalia \& Mahalli, 2012). Ketiga, faktor penyebab lainnya adalah peraturan zakat belum terlaksana secara efektif, pemerintah kurang memberi perhatian terhadap pengelolaan zakat (Kasim, 2014). Keempat, profesionalitas sumber daya manusia (Siregar, 2016). Kelima, problem pengumpulan juga pada aspek kebijakan penghimpunan zakat yang bersifat sukarela dan kurangnya insentif pajak bagi Muzaki (Bahri \& Arif, 2020). Ini selaras dengan hasil penelitian sebelumnya, bahwa zakat harus menjadi sistem wajib bukan sistem sukarela (Alfaizin et al., 2018).

Implikasinya, gap antara realisasi dan potensi pengumpulan zakat profesi terlihat masih tinggi. Masih rendahnya pengumpulan zakat, tentu bertolak belakang dengan kondisi Indonesia sebagai negara dengan penduduk muslim terbesar di dunia. Padahal, Zakat menjadi gambaran dan indikator kualitas keislaman yang diwujudkan dalam bentuk komitmen solidaritas seorang muslim dengan sesama muslim yang lain. Sebagai gambaran, jumlah muslim mencapai 87,5\% (Canggih et al., 2017; Lutfi, 2020). Apalagi posisi zakat adalah salah satu dari lima rukun Islam (Bin-Nashwan et al., 2020; Bouanani \& Belhadj, 2019)

Untuk itu, diperlukan adanya identifikasi terhadap faktor-faktor yang mendorong peningkatan pencapaian pengumpulan zakat profesi. Hasil penelitian yang dilakukan oleh Fitrianingtyas \& Nasution (2019) di Kota Surabaya menyimpulkan tiga faktor yang berpengaruh positif terhadap muzaki, yaitu: pendapatan, kepercayaan dan religiositas. Hasil penelitian selaras dengan yang dilakukan oleh Abu Bakar \& Rahis di Malaysia yang mendapati tiga faktor yang menjadi motivasi muzaki dalam pembayar zakat profesi, yaitu: faktor sosial, agama dan ekonomi (Abu Bakar \& Rashid, 2010).

Dengan demikian, menjadi penting bagi entitas pengelola zakat untuk mengenali faktor-faktor pendukung dan penghambat kesuksesan pengumpulan zakat profesi. Sebagai pelajaran, praktik keberhasilan dalam pengelolaan zakat terjadi pada masa khalifah Umar bin Abdul Azis. Salah satu faktor keberhasilan Umar bin Abdul Azis 
adalah adanya kebijakan pengelolaan keuangan publik. Model kebijakannya adalah adanya optimalisasi terhadap penerimaan negara pada berbagai sumber. Posisi zakat, menjadi sumber utama penerimaan negara. Jenis pendapatan lainnya adalah dalam bentuk jizyah, kharaj dan 'usyur. Selain itu, juga terdapat sumebr pendapatan dari ghanimah/ fai dan pajak (dharibah) (Harahap, 2016).

Secara etimologi, zakat artinya berkah, bersih, berkembang dan baik (Chaniago, 2015). Makna zakat ini, sesuai dengan yang perintahkan Alah SWT di dalam Alquran surat At-Taubah pada ayat 103 yang menjadi dasar diwajibkannya menunaikan zakat dengan tujuan untuk membersihkan dan menyucikan harta. Selanjutnya, berdasarkan pendapat Qardhawi, dalam istilah fikih, zakat diartikan sebagai sejumlah harta tertentu yang diwajibkan Allah untuk diserahkan kepada orang yang berhak menerimanya (Bahri \& Khumaini, 2020; Lubis, Deni; Hakim, Dedi Budiman; Putri, 2018). Zakat juga termasuk dalam rukun Islam ketiga dan menjadi ibadah yang berkaitan dengan aspek sosial ekonomi (Ismail et al., 2018; Rais, 2009).

Perintah wajibnya zakat langsung dari Allah SWT. Oleh karena itu, kedudukannya begitu kuat (Bahri \& Khumaini, 2020; Bahri \& Oktaviani, 2019). Ini dijelaskan dalam Alquran surat At-Taubah ayat 103. Zakat ditunaikan oleh Muzaki pada dasarnya adalah untuk keperluan muzaki guna membersihkan dan menyucikan harta. Ketika ini dipahami oleh muzaki, maka kesadaran dalam menunaikan zakat juga akan meningkat. Bagi muzaki, mestinya bersyukur dengan adanya zakat profesi ini, karena dapat memberikan peluang dan kemudahan dalam menjalankan kewajiban sebagai wujud atas keimanan dan ketaqwaan kepada Allah SWT (Ghozali et al., 2020). Oleh karena itu, zakat profesi bukan sekadar menggugurkan kewajiban, namun begitu berarti bagi mustahik ini bermanfaat untuk menguatkan kesejahteraan mustahik dalam dimensi material dan spiritual (Beik \& Arsyianti, 2015). Betapa gembiranya saudara-saudara kita yang dalam kondisi mustahik mendapatkan hak mereka. Dengan demikian, mereka mempunyai motivasi yang kuat untuk merubah kondisi dari mustahik menjadi munfiq, dan seterusnya menjadi muzaki (Bahri et al., 2019).

Dalam konteks ekonomi, zakat yang ditunaikan oleh muzaki pada dasarnya tengah terjadi pemindahan harta dari masyarakat yang berkemampuan kepada masyarakat yang tergolong mustahik (Amalia \& Mahalli, 2012). Oleh karena itu, zakat memiliki korelasi positif pada angka konsumsi sehingga dapat menggerakkan perekonomian (Sholikah, 2015). Bahkan, dengan adanya mekanisme zakat yang baik, akan terjadi peningkatan daya beli masyarakat. Dengan demikian, zakat memiliki peran yang signifikan, sehingga mampu diandalkan untuk menjaga kestabilan perekonomian. Disinilah letak peran strategis zakat profesi, keberadaannya diharapkan mampu mengatasi masalah mustahik melalui penyaluran zakat profesi dalam bentuk modal usaha (Zen, 2014).

Zakat profesi munculnya baru belakangan dengan tujuan untuk menjawab masalah perekonomian umat (Setiawan, 2011). Untuk itu, keberadaan zakat profesi menjadi penting untuk dikelola dengan serius dan aktif disosialisasikan, sehingga zakat profesi bisa menjelma kekuatan baru (Mth, 2007). Walaupun, zakat profesi tergolong jenis baru, namun termasuk dalam kategorisasi harta yang wajib dikeluarkan zakatnya (Bahri \& Arif, 2020; Mth, 2007; Setiawan, 2011). Di dalam ketentuan dan tata cara penghitungan zakat profesi/ penghasilan dijelaskan bahwa zakat profesi/ penghasilan dikenakan atas penghasilan/ pendapatan yang diperoleh oleh seseorang sebagai imbalan atas pekerjaan yang ia usahakan, secara sendiri maupun secara bersama-sama (Ketentuan Dan Tata Cara Penghitungan Zakat Profesi/ Penghasilan, 2017). Zakat 
profesi dikelurkan terhadap profesi pekerjaan baik pada sektor publik maupun swasta (Syafa et al., 2020).

Zakat profesi terkait langsung dengan kebijakan. Kebijakan pada intinya adalah sebagai pedoman untuk bertindak (Muadi et al., 2016). Kebijakan mencakup tahapan dalam menyelesaian masalah tertentu (Ely et al., 2005), proses interaksi yang dilakukan negara dengan rakyat (Suryono, 2018). Salah satu negara yang mempunyai kebijakan tentang zakat profesi adalah Sudan. Penghitungan zakat profesi di Sudan, dilakukan pada waktu penerimaan gaji dengan ketentuan, jika gaji yang diterima mencapai lebih dari kebutuhan pokok maka zakatnya langsung dikeluarga 2,5\% (Suryani, 2020). Ini menunjukkan bahwa terdapat kebijakan yang bersifat mandatory.

Kebijakan dapat dibagi menjadi dua aspek (Ely et al., 2005). Pertama, kebijakan terkait dengan aspek praktik sosial. Kedua, kebijakan terkait dengan aspek respon atas peristiwa yang terjadi. Dalam hal ini, kebijakan bertujuan untuk menciptakan harmoni dari pihak-pihak yang berkonflik, maupun menciptakan insentif atas tindakan bersama bagi para pihak yang mendapatkan perlakuan yang tidak rasional atas usaha bersama tersebut.

Selanjutnya, kebijakan publik juga mencakup sesuatu yang perlu dilakukan dan bagian yang tidak perlu dilakukan oleh pemerintah (Anindyajati \& Dharma (2019). Kebijakan publik lebih cenderung menjadi fakta strategis daripada fakta politis ataupun fakta teknis (Sururi, 2016). Pandangan lain tentang kebijakan publik, dimaknai sebagai rangkaian pilihan yang lebih kurang saling berhubungan yang mencakup tahap-tahap perumusan masalah kebijakan, implementasi kebijakan dan evaluasi kebijakan. Oleh karena itu, kebijakan publik mempunyai ruang lingkup pada publik yang menjadi lingkup bersama dalam masyarakat (Suryono, 2018).

Dari sisi proses, kebijakan publik diawali dengan pendefinisian tentang masalah kebijakan publik (Anindyajati \& Dharma, 2019). Kebijakan publik di Indonesia dapat dikelompokkan ke dalam tiga tingkatan (Septiawan and Bahri, 2019; Tahir, 2011). Pertama, kebijakan makro. Kebijakan makro mencakup kebijakan publik yang sangat mendasar, yang terdiri dari lima peraturan: (a) Undang-Undang Dasar 1945, (b) undangundang/ peraturan pengganti undang-undang, (c) peraturan pemerintah (PP), (d) peraturan presiden (perpres) dan (e) peraturan daerah (perda).

Kedua, kebijakan meso. Kebijakan meso mencakup kebijakan publik pada level menengah yang berfungsi sebagai penjelas pelaksanaan. Kebijakan meso dapat berbentuk peraturan menteri dan surat edaran menteri (pada tingkat kementerian), peraturan gubernur (tingkat provinsi), peraturan bupati/ peraturan walikota (tingkat kabupaten/ kota). Kebijakan meso juga dapat dalam bentuk surat keputusan bersama (SKB) menteri, gubernur, bupati/ walikota. Ketiga, kebijakan mikro. Kebijakan publik pada skala mikro mengatur pelaksanaan dari sebuah kebijakan. Kebijakannya dalam bentuk peraturan yang diterbitkan oleh aparat publik di bawah menteri, bupati dan walikota.

Konsep yang dikemukakan di atas sesuai dengan teori legitimasi. Bagi organisasi, legitimasi terjadi ketika masyarakat memberikan sesuatu kepada perusahaan/ organisasi. Sesuatu yang diberikan masyarakat tersebut juga menjadi keinginan dan hal yang dibutuhkan oleh perusahaan/ organisasi (Sri Utami, 2014). Menurut teori legitimasi, penting adanya pengertian kontrak sosial antara organisasi dan masyarakat (Deegan \& Unerman, 2011; Janang et al., 2020). Oleh karena itu, legitimasi sangat penting karena menjadi sumberdaya potensial bagi organisasi untuk bertahan hidup (Handoko, 2014; Utami \& Prastiti, 2011). 
Selanjutnya, menurut teori legitimasi, organisasi perlu meyakinkan masyarakat secara berkelanjutan dengan cara menyampaikan aktivitas kepada masyarakat bahwa aktivitas yang dilakukan sesuai dengan norma dan nilai yang berlaku pada masyarakat (Mandaika \& Salim, 2015). Dalam konteks zakat profesi, maka legitimasi menjadi faktor kunci keberhasilan dalam pengumpulan zakat profesi. Dengan perkembangan realisasi pengumpulan zakat profesi yang masih timpang, maka perlu dilakukan kajian mendalam tentang bentuk legitimasi yang diperoleh pad zakat profesi. Bahkan, implementasi dari teori legitimasi mendorong organisasi untuk terbuka guna meraih kepercayaan publik (Aziz \& Anim, 2020; Mustafa et al., 2013).

Berdasarkan gambaran di atas, maka peneliti tertarik untuk membahas lebih lanjut tentang zakat profesi dengan judul Analisis Zakat Profesi pada Dimensi Syariah dan Regulasi. Dengan adanya pembahasan legitimasi zakat profesi dalam perspektif syariah dan regulasi di Indonesia diharapkan dapat memberikan gambaran komprehensif tentang zakat profesi yang mencakup dimensi syariah dan regulasi. Keaslian penelitian ini adalah meninjau secara mendalam tentang legitimasi zakat profesi. Aspek yang baru dari penelitian ini adalah melakukan kajian legitimasi zakat profesi dengan dua dimensi yaitu dalam perspektif syariah dan perspektif regulasi di Indonesia. Dengan demikian, diharapkan dapat berkontribusi dalam meningkatkan realisasi pengumpulan zakat profesi mengurangi angka ketimpangan antara potensi dan realisasinya.

\section{Metode}

Penelitian ini menggunakan metode kualitatif dengan pendekatan analisis deskriptif dan studi pustaka. Analisis deskriptif digunakan untuk menjelaskan tentang zakat profesi pada dua dimensi, yaitu: syariah dan regulasi. Bahan-bahan studi pustaka didapatkan dari berbagai literatur referensi antara lain: artikel jurnal dan buku. Menurut John W. Cresswel (2014), studi literatur dilakukan untuk mendapatkan gambaran penelitian sebelumnya yang relevan dengan topik ini literatur dalam bentuk pengetahuan dasar, teori-teori, data dan informasi yang relevan.

\section{Hasil dan Pembahasan}

\section{Zakat dan Zakat Profesi}

Menurut (Ismail et al., 2018), kata zakat memiliki beberapa arti yaitu an-namaa (tumbuh dan berkembang), ath-thaharatu (kesucian), al-barakah (berkah), katsrah alkhair (banyak kebaikan), dan asy-shalahu (sukses). Embong et al. (2013) berpendapat bahwa zakat juga berarti pemurnian atau pertumbuhan. Pada artikel terbaru, Yusfiarto et al., (2020) mengungkapkan, zakat berarti berkah, tumbuh dan berkembang, kesucian.

Selanjutnya, hasil penelitian Saprida (2016) mengilustrasikan pandangan Yusuf Qardhawi tentang zakat profesi. Qardhawi berpendapat, zakat profesi merupakan zakat yang dikenakan pada tiap pekerjaan atau keahlian profesional tertentu, baik yang dilakukan sendiri maupun yang dilakukan bersama dengan orang/lembaga lain, yang mendatangkan penghasilan (uang) yang memenuhi nisab (batas minimum untuk bisa berzakat)

Menurut Qardhawi, zakat profesi sebagai pekerjaan yang menghasilkan uang terdiri dari dua kategori (Sutardi et al., 2017; Herlita, 2016). Pertama, kasb al- 'amal. Zakat profesi dikeluarkan atas pekerjaan atau upah yang dibayarkan oleh entitas perseroan atau perseorangan yang memberikan pekerjaan. Sebagai pekerja, ia terikat pada peraturan entitas dan mendapatkan upah atas pekerjaanya. Kedua, al-mihan al- 
hurrah. Zakat profesi dikeluarkan atas pekerjaan bebas dan tidak terikat pada orang lain. Contohnya adalah dokter swasta, pemborong, pengacara, para seniman, penjahit, tukang kayu dan sejenisnya.

Di dalam buku Fikih Zakat Kontekstual Indonesia dijelaskan bahwa zakat profesi dikeluarkan atas semua penghasilan kegiatan profesional. Zakat profesi menjadi wajib dikeluarkan setelah nisab (Ismail et al., 2018; Syafa et al., 2020). Hal ini sejalan dengan penelusuran yang dilakukan (Siradj, 2014), bahwa di dalam Alquran terdapat dua puluh tujuh ayat yang menyejajarkan kewajiban shalat dengan zakat dalam berbagai bentuk kata.

Selanjutnya, zakat profesi adalah zakat yang dikenakan atas penghasilan atau pendapatan yang diperoleh oleh seseorang sebagai imbalan atas pekerjaan yang ia usahakan secara sendiri maupun secara bersama-sama. Objek zakat profesi adalah untuk pekerjaan baik pada sektor publik maupun swasta. Yang menjadi penekanan adalah telah mencapai nisab. Hal ini sesuai dengan hasil muktamar pertama para ulama yang membahas tentang zakat pada tahun 1984.

Terkait dengan mustahik zakat profesi, sama halnya dengan mustahik zakat secara umum, yaitu: delapan asnaf yang terdiri dari fakir, miskin, amil, mualaf, riqab, ghorimin, ibnu sabil dan fii sabilillah. Dasar penentuan delapan asnaf ini adalah Alquran pada surat At-Taubah ayat 60. Dengan demikian, ketentuan penerima manfaat zakat sangat jelas yang mencakup delapan asnaf tersebut.

\section{Dimensi Syariah Zakat Profesi}

Pada dimensi syariah, zakat profesi mempunyai legitimasi yang kuat. Ini didasarkan pada nash-nash Alquran dan adanya kesepakatan ulama pada muktamar pertama tentang zakat dan fatwa majelis ulama indonesia (MUI) tentang zakat penghasilan. Pertama, nash-nash Alquran tentang zakat profesi. Pembahasan tentang zakat profesi terdapat di dalam nash-nash Alquran yang bersifat umum, antar lain: surat At-Taubah ayat 103, Al-Baqarah ayat 267 dan surat Adz-Dzariyat ayat 19. Kedua, kesepakatan ulama mengenai zakat pada muktamar pertama yang diselengarakan di Kuwait pada tanggal 30 April tahun 1984. Pada muktamar tersebut, para ulama telah sepakat mengenai wajibnya zakat profesi bagi yang telah mencapai nisab. Ketiga, adanya fatwa Majelis Ulama Indonesia (MUI) Nomor 3 Tahun 2003 tantang zakat penghasilan. Keempat, pandangan ulama kontemporer Yusuf Qardhawi. Sebagai padanan terkait hukum zakat profesi yang sesuai adalah pada zakat al-Mal al-Mustafad. Di mana harta diperoleh melalui satu jenis dengan proses kepemilikan yang baru dan halal (Mth, 2007)

Berdasarkan penjelasan di atas, zakat profesi mempunyai legitimasi pada dimensi syariah. Ini sama kedudukannya dengan hukum zakat mal yang lain. Menurut Asmuni keberadaaan zakat profesi termasuk yang dapat mewujudkan kemaslahatan secara simultan dalam satu waktu, yaitu: kemaslahatan pada ritual (al-masalih al-ruhiyah) kemaslahatan pada intelektual (al-masalih al-aqliyah), dan kemaslahatan pada material (al-masalih al-maddiyah). Bahkan, bila kita mengacu pada pendapat Imam As-Syatibi, maka dalam pandangan maqashid syariah terdapat lima kemaslahatan yang bisa diraih mustahik yang telah mendapatkan haknya dari dana zakat, yaitu: menyelamatkan agama (dien), menyelamatkan jiwa (nafs), menyelamatkan akal (aql), menyelamatkan keturunan (nasl) dan menyelamatkan harta (maal) (Bahri et al., 2019; Kadir et al., 2020). 


\section{Dimensi Regulasi Zakat Profesi}

Pada dimensi regulasi, zakat profesi di Indonesia diatur di dalam kebijakan publik. Kebijakan publik yang dimaksud disini mengacu pada pendapat Tahir (2011) dan Septiawan \& Bahri (2019), yang mengelompokkan kebijakan publik di Indonesia menjadi tiga tingkatan, yaitu: kebijakan publik yang bersifat makro, meso dan mikro.

Pertama, kebijakan publik pada level makro. Pada tingkatan makro, zakat profesi diatur di dalam Undang-Undang No. 23 Tahun 2011 Tentang Pengelolaan Zakat. Penjelasan tentang zakat profesi terdapat pada pasal 4 yang menyebutkan bahwa zakat meliputi zakat mal dan zakat fitrah. Zakat profesi di dalam undang-undang ini disebut dengan pendapatan dan jasa.

Ruang lingkup zakat yang luas sebagaimana tercantum di undang-undang sejalan dengan fikih kontemporer. Hakim berpendapat bahwa zakat diambil dari seluruh pendapatan yang diperoleh dari hasil pengelolaan aset fisik, finansial dan profesi atau keahlian. Artinya, potensi penerimaan dana zakat menjadi sangat signifikan (Hakim, 2016). Oleh karena itu, ketimpangan antara potensi dan realisasi zakat mestinya dapat terus diperkecil dengan mengoptimalkan kebijakan publik yang ada.

Selanjutnya, pada tingkat makro terdapat Peraturan Pemerintah Republik Indonesia No. 14 Tahun 2014. Peraturan ini merupakan pelaksanaan dari UndangUndang Pengelolaan Zakat. PP ini mengatur tentang kedudukan, tugas dan fungsi badan amil zakat nasional (BAZNAS). Dengan adanya PP ini, BAZNAS merupakan lembaga yang berwenang melakukan tugas pengelolaan zakat secara nasional. Selain itu, ada lagi Instruksi Presiden (INPRES) Nomor 3 Tahun 2014 tentang Optimalisasi Pengumpulan Zakat. INPRES ini sasarannya adalah pada tingkat pusat terdiri dari kementerian/ lembaga, sekretariat jenderal lembaga negara, sekretariat jenderal komisi negara, dan badan usaha milik negara (BUMN). Selanjutnya, pada tingkat daerah (provinsi/ kab/ kota) adalah pemerintah daerah dan badan usaha miliki daerah (BUMD). Pengumpulan zakat dilakukan melalui BAZNAS sesuai dengan tingkatannya yaitu: BAZNAS provinsi dan BAZNAS kabupaten/ kota.

Kedua, kebijakan publik pada level meso. Kebijakan ini berfungsi sebagai penjelas pelaksana. Bentuk kebijakan publik pada level meso dapat berbentuk peraturan menteri dan surat edaran menteri pada tingkat pusat. Selanjutnya, pada tingkat daerah terdapat peraturan gubernur, peraturan bupati, dan peraturan walikota. Bahkan, kebijakannya dapat pula dalam bentuk surat keputusan bersama (SKB) antar menteri, gubernur, bupati dan wali kota. Sebagai gambaran, salah satu kebijakan pada tingkat meso adalah Peraturan Menteri Agama Republik Indonesia Nomor 52 Tahun 2014. Peraturan ini mengatur mengenai syarat dan tata cara penghitungan zakat mal dan Zakat fitrah serta pendayagunaan zakat untuk usaha produktif. Pada pasal 26 ayat 1 dan 2 disebutkan bahwa nisab zakat pendapatan senilai $653 \mathrm{~kg}$ gabah/524 kg beras dan kadar zakat pendapatan dan jasa senilai 2,5\%.

Ketiga, kebijakan publik pada level mikro terkait dengan pengaturan pelaksanaan dari kebijakan yang lebih tinggi yaitu kebijakan level makro dan meso. Bentuk kebijakan mikro berupa peraturan yang diterbitkan oleh aparat publik yang berada di bawah menteri, bupati dan walikota. Sebagai contoh kebijakan level mikro adalah peraturan BAZNAS. Selain itu, juga ada peraturan yang diterbitkan oleh bupati dan wali kota terkait dengan pengumpulan zakat melalui BAZNAS.

Secara tingkatan, kebijakan publik tentang zakat profesi termasuk yang lengkap, karena ada pada setiap level baik makro, meso dan mikro. Namun, pada kebijakan publik ini masih terdapat kelemahan, di mana sifat dari pengumpulan zakat profesi ini 
masih sukarela. Untuk itu, seharusya bersifat mandatory kepada muzaki, karena semenjak zakat disyariatkan sudah bersifat wajib (Ismail et al., 2018). Dengan demikian, pengumpulan zakat profesi pun tidak berjalan maksimal, karena didasarkan pada awareness dari muzaki.

Hasil penelitian terbaru yang dilakukan di Yaman meyebutkan bahwa kompleksitas hukum zakat memiliki pengaruh negatif dan signifikan terhadap kepatuhan zakat (Bin-Nashwan et al., 2020). Implikasi dari penelitian tersebut adalah perlunya peraturan zakat yang relevan agar mampu memperkuat keyakinan agama para pembayar zakat sehingga mempunyai kepatuhan dalam mengalaman kewajiban agama terkait dengan zakat. Dengan demikian, kewajiban zakat yang menjadi rukun dalam Islam dapat dijalankan oleh umat Islam secara sempurna (Ab Rahman et al., 2012).

\section{Legitimasi Zakat Profesi}

Dalam kondisi kebijakan publik yang bersifat sukarela, maka legitimasi muzaki menjadi penting untuk diperoleh. Berbagai gap legitimasi muzaki mesti mampu diatasi. Dengan demikian, bagi lembaga pengelola zakat menjadi penting untuk mengidentifikasi aktivitasnya, mana yang akan memperkuat legitimasi dan mana yang akan memperlemah legitimasi muzaki. Sebagaimana diungkapkan Utami \& Prastiti (2011) bahwa legitimasi sangat bermanfaat atau menjadi sumber potensial bagi perusahaan/ organsasi untuk bertahan hidup.

Disinilah peran amil zakat perlu dioptimalkan untuk meningkatkan kesadaran masyarakat untuk menunaikan zakat profesi (Nugraha \& Zen, 2020). Amil zakat harus profesional (Diana, 2019), sehingga dapat menjalankan tugasnya dalam melakukan edukasi dan sosialisasi kepada masyarakat. Edukasi dan sosialisasi menjadi penting untuk mengatasi kuranganya pemahaman terhadap zakat profesi baik dari aspek hukum maupun tata cara perhitungan (Ridwan \& Triwulan, 2020). Ini sebagai upaya untuk meningkatkan pemahaman dan pengetahuan masyarakat terhadap zakat profesi.

Pengelolaan zakat di Indonesia dilakukan oleh 572 entitas pengelola zakat yang terdiri dari BAZNAS (provinsi, kabupaten/ kota) dan lembaga amil zakat (LAZ). Pengelolaan zakat dilakukan berdasarkan syariat dan Undang-Undang Nomor 23 Tahun 2011 Tentang Pengelolaan Zakat. Keberadaaan peraturan pengelolaan zakat ini sekaligus mengukuhkan peran BAZNAS sebagai lembaga yang berwenang melakukan pengelolaan zakat secara nasional.

Peraturan pengelolaan zakat ini juga menguatkan peranan BAZNAS menjadi koordinator dan sekaligus sebagai operator terbatas (Nasir et al., 2018). Bahkan BAZNAS menjadi badan resmi yang dibentuk oleh pemerintah. Pembentukan BAZNAS adalah berdasarkan Keputusan Presiden Republik Indonesia Nomor 8 Tahun 2001. Berdasarkan keputusan tersebut, BAZNAS memiliki tugas dan fungsi menghimpun dan menyalurkan zakat, infak dan sedekah (ZIS) pada tingkat nasional. Dengan demikian, BAZNAS menjadi lembaga pemerintah non-struktural yang melakukan pengelolaan zakat secara nasional di Indonesia (Bahri \& Khumaini, 2020).

Sebagai koordinator, BAZNAS berfungsi memberikan rekomendasi kepada LAZ baik tingkat nasional, provinsi dan kabupaten/kota untuk memastikan bahwa operasional LAZ dapat dipertanggung jawabkan baik dalam aspek pengumpulan mapun penyaluran ZIS dan dana sosial keagamaan lainnya (DSKL) (Ismail et al., 2018). Dengan adanya fungsi koordinator ini, maka pelaksanaan pengumpulan dan penyaluran ZIS dan DSKL dilakukan oleh LAZ secara legal sesuai dengan peraturan yang berlaku. 
Selanjutnya, sebagai operator, maka BAZNAS menjalankan aktivitas pengumpulan dan penyaluran ZIS dan DSKL dengan sangat terbatas (Nasir et al., 2018).

Selanjutnay, LAZ merupakan pengelola zakat yang diinisiasi oleh masyarakat dengan persetujuan menteri atau pejabat yang ditunjuk (Firmansyah, 2013), diprakarsai oleh kalangan masyarakat (Siradj, 2014). LAZ mendapatkan amanah utama membantu BAZNAS dalam aspek pengumpulan, pendistribusian dan pendayagunaan zakat. Dalam hal ini, LAZ yang beroperasi adalah yang telah mendapat rekomendasi dari BAZNAS dan izin menteri atau pejabat yang ditunjuk oleh menteri (Bastiar \& Bahri, 2019).

Pengelolaan zakat pada tingkat provinsi dilakukan oleh 34 entitas BAZNAS provinsi. Ini menunjukkan bahwa pengelola zakat pada tingkat provinsi jumlahnya lengkap karena mencakup semua provinsi yang ada di Indonesia. Selanjutnya, pengelolaan zakat pada tingkat kabupaten/ kota dilakukan oleh 456 entitas BAZNAS. Selain itu, pengelolaan zakat juga dilakukan oleh entitas LAZ yang dibentuk oleh masyarakat. Secara rinci, jumlah dan porsi entitas pengelola zakat di Indonesia dapat dilihat pada tabel berikut:

Tabel 1. Entitas Pengelola Zakat di Indonesia

\begin{tabular}{clcc}
\hline No. & Entitas Pengelola Zakat & Jumlah & Porsi \\
\hline 1 & BAZNAS & 1 & $0 \%$ \\
\hline 2 & BAZNAS Provinsi & 34 & $6 \%$ \\
\hline 3 & BAZNAS Kab/Kota & 456 & $80 \%$ \\
\hline 4 & LAZ Nasional & 26 & $5 \%$ \\
\hline 5 & LAZ Provinsi & 18 & $3 \%$ \\
\hline 6 & LAZ Kab/Kota & 37 & $6 \%$ \\
\hline \multicolumn{2}{r}{ Jumlah } & $\mathbf{5 7 2}$ & $\mathbf{1 0 0 \%}$ \\
\hline
\end{tabular}

Sumber: (Baznas, 2019)

Entitas pengelola zakat paling banyak adalah BAZNAS kabupaten/ kota sebesar 80\%. Dalam konteks zakat profesi, peran entitas BAZNAS kabupaten/ kota menjadi penting dalam melakukan sosialisasi dan edukasi kepada Aparatur Sipili Negara (ASN) dan pegawai swasta yang berada di wilayah masing-masing. Ini sebuah upaya untuk mengoptimalkan pengumpulan zakat profesi. Ketika zakat profesi terkumpul secara maksimal, maka penyaluran yang dijalankan secara efektif akan memberikan manfaat besar bagi kemaslahahan masyarakat. Berbagai kebutuhan dasar mustahik akan dapat terpenuhi. Berbagai program pemberdayaan pun dapat dilakukan. Dengan demikian, mustahik merasakan adanya keadilan dalam kesejahteraan.

Pada aspek pengumpulan, berdasarkan data yang dipublikasikan oleh BAZNAS jumlah pengumpulan zakat secara nasional tahun 2019 sebesar Rp10,3 triliun, di mana pengumpulan zakat profesi mencapai Rp3,95 triliun atau 38,6 persen (Baznas, 2019). Hal ini menunjukkan bahwa porsi zakat profesi termasuk yang terbesar dan menjadi andalan di dalam pengumpulan zakat nasional. Artinya, zakat profesi dalam perspektif syariah dan perspektif regulasi termasuk yang dapat dipahami dan dilaksanakan oleh penduduk muslim indonesia. Disisi lain, pengelola zakat juga perlu memberikan perhatian pada faktor-faktor positif dan negatif yang mempengaruhi minat dan niat muzaki dalam menunaikan zakat. Untuk faktor-faktor yang positif seperti kepercayaan dan religiositas, maka pengelola zakat perlu meningkatkan program edukasi dan sosialisasi. 
Walaupun, porsi realisasi pencapaian zakat profesi paling tinggi, namun apabila dibandingkan dengan potensinya, maka pencapaiannya baru sebesar $2,8 \%$. Hal ini menunjukkan bahwa diperlukan upaya optimal untuk meningkatkan realisasi pengumpulan zakat profesi. Untuk itu, dengan adanya legitimasi yang kuat terhadap zakat profesi baik dari dimensi syariah maupun dimensi regulasi, maka diperlukan strategi yang efektif dan efisien. Pertama, meningkatkan sosialisasi dan edukasi kepada muzaki khususnya aparatur sipil nasional (ASN) baik di tingkat nasional, provinsi, maupun kabupaten/kota. Ini menjadi sasaran utama dalam pengumpulan zakat. Karena, BAZNAS merupakan lembaga pemerintah non-struktural. Kedua, diperlukan adanya kebijakan pengumpulan zakat yang bersifat mandatory. Ini sebagai tindak lanjut dari penelitian sebelumnya bahwa kebijakan pengumpulan zakat yang bersifat sukarela belum efektif (Bahri \& Arif, 2020). Ketiga, diperlukan adanya skema insetif pajak bagi muzaki. Regulasi yang ada saat ini, di mana zakat menjadi pengurang pendapatan kena pajak juga termasuk yang belum efektif mendorong optimalisasi pengumpulan ZIS dan DSKL.

Selanjutnya, ketentuan penghitungan zakat profesi yang digunakan di Indonesia adalah berdasarkan Pasal I Peraturan Menteri Agama (PMA) Nomor 31 tahun 2019. Peraturan tersebut mengatur bahwa nisab zakat profesi dianalogikan pada zakat emasperak dan perdagangan. Dalam PMA disebutkan juga bahwa nisab ditetapkan sebesar 85 gram emas, sedangkan kadar zakat ditetapkan sebesar 2,5\%. Sebagai acuan, maka ketentuan harga emas berdasarkan pada harga emas pada hari tersebut. Setiap penghasilan yang melebihi Rp5.461.000,00 perbulan wajib dikeluarkan zakatnya sebesar 2,5 persen.

Dari aspek penyaluran, terdapat berbagai program penyaluran zakat profesi yang telah berjalan efektif. Penyaluran zakat profesi dilakukan semua entitas pengelola zakat yang terdiri dari BAZNAS (provinsi, kabupaten/ kota) dan LAZ. Untuk memastikan bahwa zakat profesi yang sudah terkumpul sudah disalurkan dengan baik, maka dapat dilakukan pengukuran. Salah satu model pengukuran efektivitas penyaluran Zakat adalah dengan menggunakan Model Zakat Core Principle. Proses pengukuran secara nasional dilakukan oleh BAZNAS. Hasil pengukuran tingkat efektivitas penyaluran zakat termasuk di dalamnya zakat profesi mencapai 84,9\% (Baznas, 2019). Ini menunjukkan bahwa penyaluran zakat secara nasional pada kategori efektif.

Sebagai gambaran, berikut adalah penyaluran zakat profesi yang dilakukan oleh beberapa entitas pengelola zakat. Pertama, penyaluran zakat profesi yang dilakukan oleh Kantor Kementerian Agama Kabupaten Kediri (Zahid, 2019). Penyaluran zakat profesi dilakukan pada bidang Pendidikan. Penyaluran zakat profesi ini telah berhasil menyelamatkan pendidikan anak-anak yang putus sekolah yang disebabkan oleh faktor ekonomi orang tua yang dalam posisi tidak stabil. Kedua, penyaluran zakat profesi yang dilakukan BAZNAS Kabupaten Tabanan. Penyaluran zakat profesi dilakukan pada bidang Pendidikan dalam bentuk pemberian beasiswa. Ketiga, penyaluran zakat profesi yang dilakukan Rumah Zakat Cabang Banjarmasin dalam berbagai program yang mencakup empat rumpun dengan pendekatan secara terpadu, yaitu: senyum sehat, senyum juara, senyum mandiri dan senyum lestari.

Program penyaluran zakat tentu akan makin berkembang dan meningkat manfaatnya, apabila jumlah pengumpulan zakat profesi mengalami peningkatan. Namun, apabila jumlah zakat profesi yang terkumpul masih terbatas, maka programprogram penyaluran zakat profesi juga sifatnya terbatas. Untuk itu, diperlukan upaya yang maksimal agar penyaluran zakat profesi semakin baik, akuntabel dan transparan. 
Ini akan berdampak positif terhadap pengumpulan zakat profesi. Dengan demikian, legitimasi entitas pengelola zakat juga semakin kuat.

Untuk menguatkan komitmen entitas pengelola Zakat dalam mengatasi gap antara realisasi dan potensi pengumpulan zakat profesi, maka perlu ditetapkan berbagai program strategis pada masing-masing entitas pengelola zakat. Penetapan program tersebut dapat dicantumkan dalam dokumen rencana strategis dan program tahunan masing-masing entitas pengelola zakat. Dengan demikian, ada proses kontrol dalam upaya pencapaian target pada masing-masing entitas pengelola zakat.

Berdasarkan uraian di atas, maka diperoleh gambaran bahwa kewajiban zakat profesi sama dengan kewajiban zakat mal, usaha dan pendapatan lainnya seperti: pertanian, peternakan dan perdagangan (Marimin \& Fitria, 2017). Bahkan, landasan zakat profesi terdapat di dalam Alquran disebut dengan istilah al-kasb (Sutardi et al., 2017). Oleh karena itu, kedudukan zakat profesi baik secara syariah maupun secara regulasi menjadi sangat kuat.

Untuk itu, diperlukan sosialisasi dan edukasi untuk meningkatkan awareness masyarakat dalam menunaikan zakat. Semakin besar pengumpulan zakat profesi, dapat menggambarkan adanya peningkatan kualitas iman dan takwa masyarakat. Begitu juga, semakin besar jumlah zakat yang dikumpulkan dan semakin efektif penyaluran zakat, maka manfaat yang dirasakan masyarakat dari keberadaan entitas pengelola zakat ini juga semakin besar. Ketika zakat ditegakkan, maka akan mendorong terwujdunya keadilan ekonomi. Untuk itu, para pihak yaitu: amil, muzaki dan mustahik untuk terus bahu membahu di dalam menunaikan dan menegakkan syariat zakat di tanah air.

\section{Simpulan}

Zakat profesi dalam perspektif syariah diwajibkan sesuai dengan nash Alquran dan fatwa ulama dengan ketentuan apabila telah mencapai nisab. Sedangkan zakat profesi dari perspektif regulasi di Indonesia termasuk yang lengkap mulai pada pada tingkatan makro, meso dan mikro. Dengan demikian, zakat profesi mempunyai dasar yang kokoh yang bersumber dari dimensi syariah dan dimensi regulasi. Kedua value dan keunggulan ini mestinya bisa memacu terjadinya peningkatan dalam jumlah dan kualitas pengumpulan dan penyaluran zakat.

Pada tingkat makro, zakat profesi mengacu pada Undang-Undang Nomor 23 Tahun 2011, Peraturan Pemerintah Republik Indonesia Nomor 14 Tahun 2014, dan INPRES Nomor 3 Tahun 2014. Pada tingkat meso, zakat profesi mengacu pada Peraturan Menteri Agama Nomor 52 Tahun 2014 tentang Syarat dan Tata Cara Penghitungan Zakat Mal dan Zakat Fitrah serta Pendayagunaan Zakat untuk Usaha Produktif. Sedangkan pada tingkat mikro, zakat profesi diatur di dalam peraturan BAZNAS dan peraturan yang diterbitkan oleh kepala daerah.

Walaupun secara tingkatan, kebijakan publik tentang zakat profesi termasuk yang lengkap, karena ada pada setiap level baik makro, meso dan mikro, namun, pada kebijakan publik ini masih terdapat kelemahan, di mana sifat dari pengumpulan zakat profesi ini masih bersifat sukarela, yang seharusya adalah bersifat mandatory kepada muzaki, karena semenjak zakat disyariatkan sudah bersifat wajib. Hal inilah yang menjadi salah satu sebab pengumpulan zakat profesi belum berjalan maksimal, karena hanya didasarkan pada awareness dari muzaki.

Dalam kondisi kebijakan publik yang bersifat sukarela, maka legitimasi muzaki menjadi penting untuk diperoleh. Legitimasi entitas pengelola zakat juga dapat dijaga dan ditingkatkan dengan cara menjaga kepercayaan dari muzaki. Kepercayaan muzaki 
dapat ditingkatkan dengan cara mengoptimalkan edukasi dan sosialisasi. Selain, itu perlu menjadi perhatian bagi entitas pengelola zakat untuk meningkatkan pelayanan kepada muzaki. Pelayanan, dapat dilakukan dalam bentuk kemudahan dalam layanan tranfer zakat, serta pemutakhiran laporan aktivitas yang sedang berajalan, serta menjaga kualitas laporan audit (keuangan dan syariah) dalam kategori wajar dan sesuai syariah.

Penelitian ini menggunakan pendekatan studi pustaka yang sumber datanya diperoleh dari jurnal dan buku yang terkait dengan tema. Oleh karena itu, diperlukan selanjutnya untuk memperluas metodologi penelitian dengan melakukan observasi dan wawancara langsung dengan pemangku kepentingan pengelolaan zakat nasional, karena dalam perspektif syariah dan regulasi sudah sangat mendukung. Oleh karena itu, perlu dilakukan penelusuran lebih lanjut pada tingkat implementasi baik implementasi kebijakan maupun implementasi pada lembaga pengelola zakat.

\section{Referensi}

Ab Rahman, A., Alias, M. H., \& Omar, S. M. N. S. (2012). Zakat institution in Malaysia: Problems and issues. Global Journal Al-Thaqafah, 2(1), 35-41. https://doi.org/10.7187/GJAT122012.02.01

Abu Bakar, N. B., \& Rashid, H. M. A. (2010). Motivations of Paying Zakat on Income: Evidence from Malaysia. International Journal of Economics and Finance, 2(3), 76-84. https://doi.org/10.5539/ijef.v2n3p76

Aibak, K. (2015). Zakat Dalam Perspektif Maqashid Al-Syariah. Ahkam: Jurnal Hukum Islam, 3(2), 199-218. https://doi.org/10.21274/ahkam.2015.3.2.199-218

Alfaizin, A. W., Insani, T. D., \& Herianingrum, S. (2018). Zakat: Concept and Implications To Social and Economic (Economic Tafsīr of Al-Tawbah:103). Journal of Islamic Monetary Economics and Finance, 4(1), 117-132. https://doi.org/10.21098/jimf.v4i1.780

Amalia, A., \& Mahalli, K. (2012). Potensi dan Peranan Zakat dalam Mengentaskan Kemiskinan di Kota Medan. Jurnal Ekonomi Dan Keuangan, 1(1), 14869.

Anindyajati, P., \& Dharma, A. V. (2019). Faktor-Faktor yang Mempengaruhi Implementasi Pedoman Pelaksanaan Sistem Pengendalian Intern Pemerintah sebagai Suatu Bentuk Kebijakan Publik. Faktor-Faktor Yang Mempengaruhi Implementasi Pedoman Pelaksanaan Sistem Pengendalian Intern Pemerintah Sebagai Suatu Bentuk Kebijakan Publik, 7(2), 51-60. https://doi.org/10.17509/jrak.v7i2.17039

Aziz, M. R. A., \& Anim, N. A. H. M. (2020). Trust towards zakat institutions among muslims business owners. Jurnal Ekonomi \& Keuangan Islam, 6(1), 1-9. https://doi.org/10.20885/jeki.vol6.iss1.art1

Bahri, E. S., \& Arif, Z. (2020). Policy Analysis of Zakat Profession in Indonesia. Test Engineering and Management, 83(May-June), 29059-29067.

Bahri, E. S., Aslam, M. M. A., Hj Hasan, A. A., \& Wibowo, H. (2019). Maqasid AlShariah in Micro-entrepreneurs Development: an Overview. International Conference of Zakat, 258-267. https://doi.org/10.37706/iconz.2019.182

Bahri, E. S., \& Khumaini, S. (2020). Analisis Efektivitas Penyaluran Zakat pada Badan Amil Zakat Nasional. Al Maal: Journal of Islamic Economics and Banking, 1(2), 164-175. https://doi.org/10.31000/almaal.v1i2.1878

Bahri, E. S., \& Oktaviani, R. (2019). Zakat Produktif Sebagai Modal Kerja Usaha Mikro. Perisai: Islamic Banking and Finance Journal, 2(2), 101. https://doi.org/10.21070/perisai.v2i2.1686 
Bastiar, Y., \& Bahri, E. S. (2019). Model Pengkuran Kinerja Lembaga Zakat di Indonesia. ZISWAF: Jurnal Zakat Dan Wakaf, 6(1), 43. https://doi.org/10.21043/ziswaf.v1i1.5609

Baznas. (2019). Statistik Zakat Nasional 2019 (National Zakat Statistics 2019). In Baznas. Baznas.

Ketentuan dan Tata Cara Penghitungan Zakat Profesi/Penghasilan, Berita Resmi Puskas BAZNAS (2017).

Beik, I. S., \& Arsyianti, L. D. (2015). Construction of Cibest Model As Measurement of Poverty and Welfare Indices From Islamic Perspective. Al-Iqtishad: Journal of Islamic Economics, 7(1), 87-104. https://doi.org/10.15408/ijies.v7i1.1361

Bin-Nashwan, S. A., Abdul-Jabbar, H., Aziz, S. A., \& Haladu, A. (2020). Zakah compliance behavior among entrepreneurs: economic factors approach. International Journal of Ethics and Systems, 36(2), 285-302. https://doi.org/10.1108/IJOES-09-2019-0145

Bouanani, M., \& Belhadj, B. (2019). Zakat and Poverty Alleviation in Tunisia Using the Fuzzy Approach. Journal of Quantitative Economics, 17(2), 421-432. https://doi.org/10.1007/s40953-019-00154-2

Canggih, C., Fikriyah, K., \& Yasin, A. (2017). Potensi Dan Realisasi Dana Zakat Indonesia. Al-Uqud: Journal of Islamic Economics, 1(1), 14. https://doi.org/10.26740/jie.v1n1.p14-26

Chaniago, S. A. (2015). Pemberdayaan Zakat Dalam Mengentaskan Kemiskinan. Jurnal Hukum Islam, 13(1), 47. https://doi.org/10.28918/jhi.v13i1.495

Diana, Z. A. (2019). The Welfare of Amil Zakat in Dompet Dhuafa, Central Java. Journal of Islamic Economics Management and ..., 1(1). https://doi.org/10.21580/jiemb.2019.1.1.3836

Ely, L., Lobenberg, R., Finlay, W. H., \& Roa, W. H. Y. (2005). Optimizing inhalable nanoparticles. Proceedings - 2005 International Conference on MEMS, NANO and Smart Systems, ICMENS 2005, 125-126. https://doi.org/10.1109/ICMENS.2005.96

Embong, M. R., Taha, R., \& Nor, M. N. M. (2013). Role of zakat to eradicate poverty in Malaysia. Jurnal Pengurusan, 39(2013), 141-150. https://doi.org/10.17576/pengurusan-2013-39-13

Firdaus, M., Beik, I. S., Irawan, T., \& Juanda, B. (2012). Economic estimation and determinations of Zakat potential in Indonesia. IRTI Working Paper Series, WP 1433-07(August), 1-74.

Firmansyah. (2013). Zakat Sebagai Instrumen Pengentasan Kemiskinan dan Kesenjangan Pendapatan. Jurnal Ekonomi Dan Pembangunan, 21(2), 179-190. https://doi.org/10.14203/JEP.21.2.2013.61-72

Fitrianingtyas, R., \& Nasution, Z. (2019). Peran Muzakki Terhadap Intensi Zakat Profesi Kota Surabaya. Jurnal Masharif Al-Syariah: Jurnal Ekonomi Dan Perbankan Syariah, 4(2), 173-186.

Ghozali, M., Zaid, A. H., Nadhira, A., \& Fauziah, R. (2020). Zakat Analysis of Freelancer Profession. 1st Borobudur International Symposium on Humanities, Economics, and Social Sciences (BIS-HESS 2019), 436, 245-248. https://doi.org/10.2991/assehr.k.200529.050

Hakim, B. R. (2016). Analisis Terhadap Undang-Undang Nomor 23 Tahun 2011 Tentang Pengelolaan Zakat (Perspektif Hukum Islam). Syariah Jurnal Hukum Dan Pemikiran, 15(2), 155-166. https://doi.org/10.18592/syariah.v15i2.552

Handoko, Y. (2014). Implementasi Social and Environmental Disclosure dalam 
Perspektif Teoritis. Jurnal JIBEKA, 8(1), 72-77.

Harahap, K. (2016). Kebijakan Pengelolaan Keuangan Publik Pada Masa Kekhalifahan Umar Bin Abdul Aziz. Jurnal Ipteks Terapan, 8(2), 58-69. https://doi.org/10.22216/jit.2014.v8i2.424

Herlita, J. (2016). Manajemen Pengelolaan Zakat Profesi di Rumah Zakat Cabang Banjarmasin. Alhiwar Jurnal Ilmu Dan Teknik Dakwah, 04(08), 51-64.

Islamiah, S., \& Romli, S. (2019). Persepsi Guru PNS Kecamatan Mersam Kabupaten Batanghari Provinsi Jambi terhadap Zakat Profesi. Jurnal Riset Mahasiswa Dakwah Dan Komunikasi (JRMDK), 1(5), 54-55. https://doi.org/10.24014/jrmdk.v1i5.8881

Ismail, A. S., Mas'udi, M. F., Bahri, E. S., Halim, I., Tajang, M. N., Qasim, F., Hambali, A., \& Erianton, P. (2018). Fikih Zakat Kontekstual Indonesia. Baznas.

Janang, J. S., Joseph, C., \& Said, R. (2020). Corporate governance and corporate social responsibility society disclosure: The application of legitimacy theory. International Journal of Business and Society, 21(2), 660-678.

John W. Cresswel. (2014). Research Design: Qualitative, Quantitative, and Mixed Methods Approaches. In Journal of Petrology (Vol. 369, Issue 1). SAGE Publications, Inc.

Kadir, A., Hakim, M. R., Syam, F., \& Karim, M. S. (2020). Pengunaan Dana Zakat Pada Korban Covid-19 Perspektif Maqashid Syariah. Al-Tafaqquh: Journal of Islamic Law, 1(2), 107. https://doi.org/10.33096/al-tafaqquh.v1i2.61

Kasim, N. M. (2014). Paradigma zakat profesi dalam kehidupan masyarakat gorontalo. Al-Hurriyah, 15(1), 78.

Lubis, Deni; Hakim, Dedi Budiman; Putri, Y. H. (2018). Mengukur kinerja pengelolaan zakat di badan amil zakat nasional (baznas). JEBI (Jurnal Ekonomi Dan Bisnis Islam), 3(23), 1-16.

Lutfi, M. (2020). Peran Negara Dalam Optimalisasi Zakat Perspektif Konstitusi Ekonomi. Sakina: Journal of Family Studies, 4(1), 1-10. https://doi.org/10.18860/jfs.v4i1.430

Mandaika, Y., \& Salim, H. (2015). Pengaruh Ukuran Perusahaan, Kinerja Keuangan, Tipe Industri, dan Financial Leverage terhadap Pengungkapan Corporate Social Responsibility: Studi Empiris pada Perusahaan Manufaktur yang Terdaftar di Bursa Efek Indonesia Tahun 2011-2013. Jurnal Akuntansi, 8(2), 181-201. https://doi.org/10.25170/jara.v8i2.18

Marimin, A., \& Fitria, T. N. (2017). Zakat Profesi (Zakat Penghasilan) Menurut Hukum Islam. Jurnal Ilmiah Ekonomi Islam, 1(01), 50-60. https://doi.org/10.29040/jiei.v1i01.9

Mth, A. (2007). Zakat Profesi dan Upaya Menuju Kesejahteraan Sosial. La_Riba, 1(1), 43-56. https://doi.org/10.20885/lariba.vol1.iss1.art4

Muadi, S., MH, I., \& Sofwani, A. (2016). Konsep dan Kajian Teori Perumusan Kebijakan Publik. Jurnal Review Politik, 6(2), 195-224. http://jurnalpolitik.uinsby.ac.id/index.php/jrp/article/view/90

Mustafa, M. O. A., Mohamad, M. H. S., \& Adnan, M. A. (2013). Antecedents of zakat payers' trust in an emerging zakat sector: an exploratory study. Journal of Islamic Accounting and Business Research, 4(1), 4-25. https://doi.org/10.1108/17590811311314267

Nasir, M., Bahri, E. S., Purwakananta, M., Tohir, K. ., Adinugroho, A. S., Qasim, F., Hidayat, D., Anriani, Sidik, R., Hambali, A., \& Hanum, K. (2018). Rencana 
Strategis 2016-2020 Badan Amil Zakat Nasional.

Nugraha, W., \& Zen, M. (2020). Peran Amil Zakat dalam Meningkatkan Kesadaran Zakat Profesi Pada Laznas Al-Azhar Jakarta Selatan. Al Maal: Journal of Islamic Economics and Banking, 1(2), 176. https://doi.org/10.31000/almaal.v1i2.2274

Puskas. (2019). Indikator Pemetaan Potensi Zakat (IPPZ) (Issue July). Puskas.

Rais, I. (2009). Muzakki dan Kriterianya Dalam Tinjauan Fikih Zakat. Al-Iqtishad: Jurnal Ilmu Ekonomi Syariah, 1(1), 91-106. https://doi.org/10.15408/aiq.v1i1.2456

Ridwan, M., \& Triwulan, A. (2020). Implementation of Professional Zakat on Employee Income at Sitopeng Public Health Center (PHC) Cirebon City. Journal of Social Science, 1(4), 142-146. https://doi.org/10.46799/jsss.v1i4.49

Riyadi, F. (2015). Kontroversi zakat profesi pesrpektif ulama kontemporer. ZISWAF, 2(2), 109-132. https://doi.org/10.21043/ziswaf.v2i1.1538

Saprida. (2016). Zakat Profesi Menurut Pandangan Yusuf Qardhawi. Economica Sharia , 2(1), 49-57.

Septiawan and Bahri. (2019). Tinjauan Zakat Perusahaan Perspektif Syariah Dan Regulasi. Sekolah Tinggi Ekonomi Islam SEBI Indonesia, 7(2), 1-16. https://doi.org/10.15408/kordinat.v18i2.11495

Setiawan, D. (2011). Zakat Profesi dalam Pandangan Islam. Jurnal Sosial Ekonomi Pembangunan, 1(2), 195-208.

Sholikah, M. A. (2015). Regulasi Zakat Di Indonesia; Upaya Menuju Pengelolaan Zakat Yang Profesional. Tafaqquh: Jurnal Penelitian Dan Kajian Keislaman, 3(1), 3665.

Siradj, M. (2014). Jalan Panjang Legislasi Syariat Zakat di Indonesia : Studi terhadap Undang- Undang Nomor 23 Tahun 2011 tentang Pengelolaan Zakat. Jurnal Bimas Islam, 7(3), 409-448.

Siregar, S. (2016). Problematika Fundraising Zakat: Studi Kasus BAZNAS di Sumatera Utara. MIQOT: Jurnal Ilmu-Ilmu Keislaman, 40(2), 247-267. https://doi.org/10.30821/miqot.v40i2.299

Sri Utami, S. D. P. (2014). Pengaruh Karakteristik Perusahaan Terhadap Enviromental Disclosure. None, 3(3), 188-198.

Sururi, A. (2016). Inovasi Kebijakan Publik (Tinjauan Konseptual dan Empiris). Jurnal Sawala, 4(3), 1-14. https://doi.org/10.30656/sawala.v4i3.241

Suryani, E. (2020). Zakat Infak Sodaqoh Sebagai Instrumen Pertumbuhan Ekonomi di Indonesia. As-Syar'i : Jurnal Bimbingan \& Konseling Keluarga, 2(2), 119-133. https://doi.org/10.47467/as.v2i2.127

Suryono, A. (2018). Kebijakan Publik Untuk Kesejahteraan Rakyat. Transparansi Jurnal Ilmiah Ilmu Administrasi, 6(2), 98-102. https://doi.org/10.31334/trans.v6i2.33

Sutardi, Irwan, M., \& Ro'is, I. (2017). Implementasi Kaidah-Kaidah Islam dalam Pengelolaan Zakat Profesi. Al Masraf: Jurnal Lembaga Keuangan Dan Perbankan, Volume 2(Nomor 1), 97-109. https://doi.org/10.15548/al-masraf.v2i1.94

Syafa, A. K., Ferawati Ekaningsih, L. A., Inayah, N., Jauhariyah, N. A., \& Fathurrohman, A. (2020). The management of professional Zakat in overcoming the poverty in Tegalsari district regency of Banyuwangi East Java Indonesia. Proceedings of the International Conference on Industrial Engineering and Operations Management, O(March), 2073-2080.

Tahir, A. (2011). Kebijakan Publik dan Transparansi Penyelenggaraan Pemerintahan 
Daerah. Penerbit Alfabeta.

Tan, J. A. M. A., Lee, P. C., Wee, Y. C., Tan, K. L., Mahali, N. F., George, E., \& Chua, K. H. (2010). High prevalence of alpha- and beta-thalassemia in the kadazandusuns in east Malaysia: Challenges in providing effective health care for an indigenous group. Journal of Biomedicine and Biotechnology, 2010(2), 36-45. https://doi.org/10.1155/2010/706872

Utami, S., \& Prastiti, S. D. (2011). Pengaruh Karakteristik Perusahaan Terhadap Social Disclosure. Jurnal Ekonomi Bisnis, 16(1), 63-69.

Yusfiarto, R., Setiawan, A., \& Nugraha, S. S. (2020). Literacy and Intention to Pay Zakat: A Theory Planned Behavior View Evidence from Indonesian Muzakki. International Journal of Zakat, 5(1), 15-27.

Zahid, R. A. (2019). Optimalisasi Pemanfaatan Zakat Profesi Kantor Kementerian Agama Kabupaten Kediri di Sektor Pendidikan. Jurnal Intelektual: Jurnal Pendidikan Dan Studi Keislaman, 9(2). https://doi.org/10.33367/ji.v9i2.1016

Zen, M. (2014). Zakat Profesi sebagai Distribusi Pendapatan Ekonomi Islam. Human Falah: Jurnal Ekonomi Dan Bisnis Islam, 1(1), 63-91. 